\title{
Modeling of the lifting of a heat transfer agent in a geothermal well of a gas condensate deposit
}

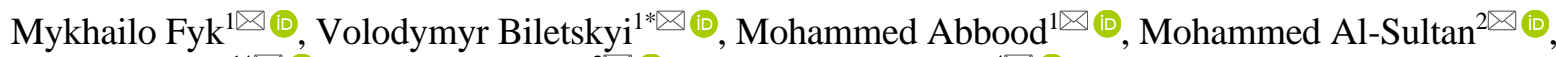

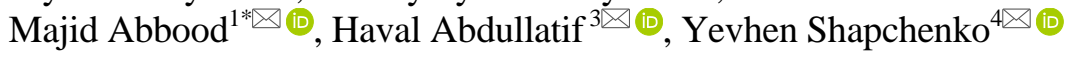 \\ ${ }^{I}$ National Technical University "Kharkiv Polytechnic Institute”, Kharkiv, 61002, Ukraine \\ ${ }^{2}$ LLC Weatherford Ukraine, Kyiv, 03150, Ukraine \\ ${ }^{3}$ Brightpetrozone Co., Erbil, 92001, Iraq \\ ${ }^{4} U M G$ "Kharkivstransgaz", Kharkiv, 61002, Ukraine \\ *Corresponding author: e-mail biletsk@i.ua, tel. +380677178068
}

\begin{abstract}
Purpose is to develop mathematical model of nonisothermal inflow and lifting of the recovered gaseous mixture (i.e. geothermal fluid) of a well taking into consideration dynamic coefficient of heat transfer and thermal diffusion coefficient; fluid expansion coefficient in terms of nonadiabatic process; effect of average integral environmental temperature on the heat transfer coefficient; changes in molar mass of the fluid during the well operation; and a process of the productive seam cooling during initial development stages (i.e. months-years).

Methods of material and energy balance of fluid-heat flows within a productive formation and within a well as well as forecasting of geothermal fluid production; numerical methods of fluid thermal gas dynamics; Runge-Kutta $4^{\text {th }}$ order method; and Quazi-Newton method to solve nonlinear equations have been applied.

Findings. It has been demonstrated that thermal gradient of rocks and thermal carrier-rock heat exchange vary depending upon operation modes of the formation and the well in terms of temperature effect, temperature difference in humidity, viscosity, compressibility, and other rock characteristics determining efficiency of thermal diffusion as well as coefficient of heat exchange between the fluid and rocks.

Originality. The specified equations of thermal energy balance in terms of radial filtration and well product lifting have been developed. The equations are more preferable to compare with the current calculation technique, where a coefficient of fluid is expanded in a seam in the context of nonadiabatic process, and consideration of effect of average integral environment temperature of the heat transfer strength (the known methods takes into account geometric mean of the formation temperature). Actual changes in molar mass of the produced geothermal fluid during the whole period of the well operation (i.e. up to 50 years) are involved. Thermal gas dynamic model well inflow-lifting has been improved owing to the consideration of a transient process of the productive formation cooling during the initial stage of the geothermal fluid production (i.e. months-years).

Practical implications. The developed mathematical model helps specify calculation of a well yield by $10-15 \%$. To compare with the standard methods, the model makes it possible to perform 20-30\% specification of heat output by a gas condensate well in terms of thermobaric intensification of the fluid production as well as in terms of binary techniques of fluidgeoheat generation.
\end{abstract}

Keywords: yield of geothermal fluid, thermal gradient, rock, parametric temperature full-scale, heat exchange coefficient, Joule-Thompson effect

\section{Nomenclature}

$C_{p}$ - specific heat capacity $(2200-2500 \mathrm{~J} / \mathrm{kg} \mathrm{K})$;

$D$ - pipe diameter $(0.073 \mathrm{~m})$

$K_{t}-$ heat transfer coefficient $\left(1-3 \mathrm{~W} / \mathrm{m}^{2} \mathrm{~K}\right)$;

$R_{k}$ - fluid drainage diameter across the reservoir $(300 \mathrm{~m})$;

$k$ - permeability of reservoir layer $\left(3.00 \mathrm{E}^{-11} \mathrm{~m}^{2}\right)$;

$H$ - depth $(3500 \mathrm{~m})$;

$M_{q}$ - mass flow rate $(1-6 \mathrm{~kg} / \mathrm{s})$;

$\mathrm{Nu}$ - Nusselt number (100);

$\mathrm{Pr}$ - Prandtl number (1);

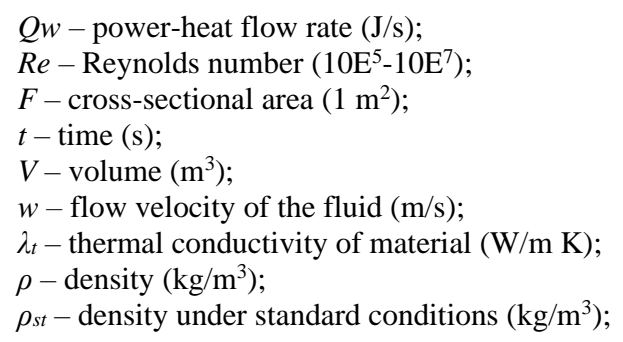


$x$ - distance $(\mathrm{m})$;

$P_{w h}$ - absolute upstream pressure $(\mathrm{Pa})$;

$P_{b h}-$ absolute downstream pressure $(\mathrm{Pa})$;

$L_{p}$ - length of pipe (m);

$d$-inside diameter of pipe (m);

$z$ - factor of compressibility;

$\Delta$ - specific gravity, relative density;

$\lambda$ - factor of hydraulic resistance;

$\Delta H$ - a difference of heights (m);

$P_{p l}$ - rock layer pressure $(\mathrm{Pa})$;

$T_{p l}$ - rock layer temperature (K);

$D_{j}$ - Joule-Thomson coefficient (K/MPa);

$R$ - gas constant $(\mathrm{J} /(\mathrm{kg} \cdot \mathrm{K}))$;

$T_{o}$ - ground temperature (K);

$P$ - pressure $(\mathrm{Pa})$;

$T$ - temperature, $(\mathrm{K})$;

$P_{1}$ - pressure absolute the source $(\mathrm{Pa})$;

$P_{2}-$ pressure absolute the receiver $(\mathrm{Pa})$;

$\mu$ - dynamic viscosity $(\mathrm{Pa} \cdot \mathrm{S})$;

$M$ - molar mass $(\mathrm{kg} / \mathrm{mol})$;

$k_{e}$ - roughness inside the pipe (m);

$\varphi_{t}$ - nonisothermal correction factor;

$h$ - high of layer (m);

$P_{a t}-$ atmospheric pressure $(\mathrm{Pa})$;

$T_{a t}$ - atmospheric temperature (K);

$A$-linear coefficient of reservoir filtration resistance $\left(\left(\mathrm{MPa}^{2}\right) /\right.$

(Thnd. ${ }^{3} /$ day));

\section{Introduction}

A process of design of geothermal deposits as well as oilgas full-scales involves the use of both standard and specified techniques forecasting the basic production parameters. After bringing into operation, long-term operation, and repair, wells need determination of possible rational performance modes which stipulates the necessity of constant improvement of calculation techniques for operating parameters of a well and fluid yield [1]. The latter is determined with the help of a number of factors; first of all, it concerns hydrocarbons inflow to well bottom zone and operating mode of intra formational filtration. Fluid evacuation through a production string to the surface also influences heavily forecasting of the production of gas condensate wells. In turn, fluid lifting depends, among other things, upon heat transfer of drill string rocks and their thermal gradient. Such a multifactor nature and interconnection of inflow-lifting processes complicate the calculations. In other words, many authors analyzed temperature within a centre point between a stope and a boundary of draining radius of rock parameters, actual curves of temperature distribution along a well, and heat exchange between the produced fluid and adjoining rocks [2] supporting interest of the dedicated experts. However, the current calculation techniques cannot involve fluid expansion coefficient in terms of nonadiabatic process, effect of average integral environmental temperature on the heat transfer coefficient, and changes in molar mass of the fluid during the well operation. Moreover, the popular studies do not involve a process of the productive seam cooling during initial stages of well operation (i.e. months-years) [3]-[5]. Hence, it is important to formalize a relevant problem of specified evaluation of yield of gas condensate wells with the essentially nonisothermal operation mode, and to practise innovative scientific approaches. The paper considers a simple model of gas condensate well inclusive of the fact it operates from one productive formation while having one lifting drill string; in terms of depth, geothermal gradient remains constant. It is
$B$ - second coefficients of reservoir filtration resistance $\left(\left(\left(\mathrm{MPa}^{2}\right) /\left(\text { Th-nd. } \mathrm{m}^{3} / \text { day }\right)^{2}\right)\right)$;

$C$ - constant coefficients of reservoir filtration resistance $\left(\mathrm{MPa}^{2}\right)$;

$P_{p c}$ - pseudocritical pressure $(\mathrm{Pa})$;

$T_{p c}$ - pseudocritical temperature $(\mathrm{K})$;

$R_{c}$ - radius off well productive pipe (m);

$P_{b h}$ - borehole pressure $(\mathrm{Pa})$;

$P_{w h}-$ wellhead pressure $(\mathrm{Pa})$;

$S$ - skin factor;

$z_{s t}$ - compressibility under standard conditions;

$k_{o}$ - coefficient of accommodation;

$j, n$ - degree parameters in the Newselt number equation;

$P_{\text {rav }}$ - average pressure of rock layer $(\mathrm{Pa})$;

$T_{\text {rav }}$ - average temperature of rock layer $(\mathrm{K})$;

$R_{\text {air }}$ - gas constant air $(\mathrm{J} / \mathrm{kg} \mathrm{K})$;

$R_{\mu}$ - universal gas constant $(\mathrm{J} / \mathrm{Kmol} \mathrm{K})$;

$\alpha$ - coefficient of thermal expansion of fluid;

$S_{1}-$ skin factor for coefficient $A$;

$S_{2}-$ skin factor for coefficient $B$;

$g$ - Accelerating gravity $\left(\mathrm{m} / \mathrm{s}^{2}\right)$;

$N_{n g}$ - factor in the fluid flow equation to the well bore;

$\beta$-coefficient of macro-rigidity of the rock of the productive formation; $K_{a}$ - the coefficient of annihilation of the effect of throttling;

$\beta_{a}$ - coefficient of annihilation of change of thermal conductivity depending on dynamic temperature;

$K_{t o}$ - heat transfer coefficient for primitive geothermal gradients;

$\Delta T_{t e}$-temperature change of gas condensate fluid in the drained part of the reservoir due to heat exchange.

common practice to introduce into mathematical model equations of inflow to a well face as well as lifting. It is required to compare modeling results with the full-scale studies of actual wells since depth facilities recorded significant influence of Joule-Thomson effect starting from a well bottom zone.

Equation of gas condensate mixture inflow from the drained area of a productive formation to a well bottom is entered up with the use of such filtration coefficients as $A, B$, and $C$ generally determining natural gas output per certain period [1], [2]:

$$
\begin{aligned}
& \left(\frac{P_{p l}}{10^{6}}\right)^{K_{n g}}-\left(\frac{P_{b h}}{10^{6}}\right)^{K_{n g}}=A \cdot\left(\frac{M_{q} \cdot 24 \cdot 3600}{\rho \cdot 1000}\right)+ \\
& +B \cdot\left(\frac{M_{q} \cdot 24 \cdot 3600}{\rho \cdot 1000}\right)^{2}+C,
\end{aligned}
$$

where:

$$
\begin{aligned}
& A=\frac{z \cdot \mu \cdot P_{a t} \cdot T_{r a v}}{\pi \cdot k \cdot h \cdot T_{a t}} \cdot\left(\ln \left(\frac{R_{k}}{R_{c}}\right)+S_{1}\right) \\
& B=\frac{z \cdot \beta \cdot P_{a t}^{2} \cdot T_{r a v}}{2 \cdot \pi^{2} \cdot \sqrt{k} \cdot h^{2} \cdot T_{a t}^{2} \cdot z_{s t} \cdot R} \cdot\left(\ln \left(\frac{1}{R_{c}}-\frac{1}{R_{k}}\right)+S_{2}\right) ;
\end{aligned}
$$

$K_{n g}=2$ (for gaseous fluid), and $K_{n g}=1$ (for fluids).

SI system has been used in formula (1) and henceforth.

It should be noted that in the process of filtration motion of oil fluid through a seam, heat-mass-exchange process and adiabatic expansion take place which can be described using equation from [3]:

$$
T_{p l}-T_{b h}=D_{j}\left(P_{p l}-P_{b h}\right)+\Delta T_{h e},
$$

where:

$\Delta T_{h e}$ - determined experimentally for the conditions of a specific geothermal reservoir. 
Comparison of the thermal flow values with a well heat production (i.e. output of the geothermal well) using dynamic thermal gradients and thermal conductivity [2] shows that ignorance of influence of seam pressures and temperatures on the heat transfer of adjoining rocks results either in the overvaluation of the thermal flow or in its undervaluation [4], [6].

On the way from a seam towards a well bottom, compressibility $\mathrm{z}$, isobaric thermal capacity $C_{p}$, dynamic viscosity $\mu$, and density of natural hydrocarbons $\rho$ as well as JouleThompson coefficient $D_{j}$ will vary significantly depending upon actual pressure $P$ and temperature $T$ [4]. As for the natural gases with more than $90 \%$ methane content, molar mass $M=$ const and standard density $\rho_{s t}=$ const, they can be determined according to following empiric functional dependences of Latonov-Gurevich, Starling-Ellington, and Lurie [5], [7]:

$$
\begin{aligned}
& z\left(P, T, \rho_{s t}\right)=\frac{0.1 \cdot P}{P_{p c}\left(\rho_{s t}\right)}+ \\
& +\left[0.4 \cdot \log \left(\frac{T}{T_{p c}\left(\rho_{s t}\right)}\right)+0.73\right]^{\frac{P}{P_{p c}\left(\rho_{s t}\right)}} ; \\
& \mu(P, T, M)=\frac{(9.41+0.02 \cdot M) \cdot(1.8 \cdot T)^{1.5}}{(209+19 \cdot M+1.8 \cdot T) \cdot 10^{7}} \times \\
& \exp \left(\left(3.5+\frac{547.8}{1.8 \cdot T}+0.01 \cdot M\right) \times\right. \\
& \times\left(\frac{P \cdot 10^{3}}{\left.z\left(P, T, \rho_{s t}\right) \cdot \frac{8314.3}{M} \cdot T\right)}\right)\left(2.4-0.2\left(3.5+\frac{547.8}{1.8 T}+0.01 \cdot M\right)\right) \\
& \left(\begin{array}{c}
D_{j} \\
C_{p}(P, T, M)=\frac{1-a \cdot T}{C_{p}(P, T, M) \cdot \rho(P, T, M)}, \\
\left.+2170 \cdot 1.015^{P \cdot 10^{-6}} \cdot p^{0.0214}\right) \cdot\left(\frac{R_{a i r} \cdot M}{0.6 \cdot R_{\mu}}\right)^{0.025}
\end{array} ;\right.
\end{aligned}
$$

where:

$$
T_{p c}\left(\rho_{s t}\right)=88.25 \cdot\left(0.9915+1.759 \cdot \rho_{s t}\right) \text {; }
$$

$P_{p c}\left(\rho_{s t}\right)=2.9585 \cdot\left(1.608-1.05994 \cdot \rho_{s t}\right)$ are pseudocritical parameters of gas-condensate mixture;

$$
\rho(P, T, M)=\frac{P}{z(P, T, M) \cdot R \cdot T}-\text { the mixture density }
$$

under working conditions.

After passing through penetrating zone of a productive formation, gas condensate mixture is evacuated via the oil string having active heat transfer with rocks adjoining the well [6] which is understood from a schematic view of a seamwellbottom zone-well system in Figure 1. Double-headed arrows explain heat transfer between adjoining rocks and mobile fluid (i.e.thermal medium) first passing through a filtration area within the seam (being demonstrated in the form of unidirectional arrows); then, passing through a wellbottom zone (shown as green-contoured) it goes up via production tubing (PT).

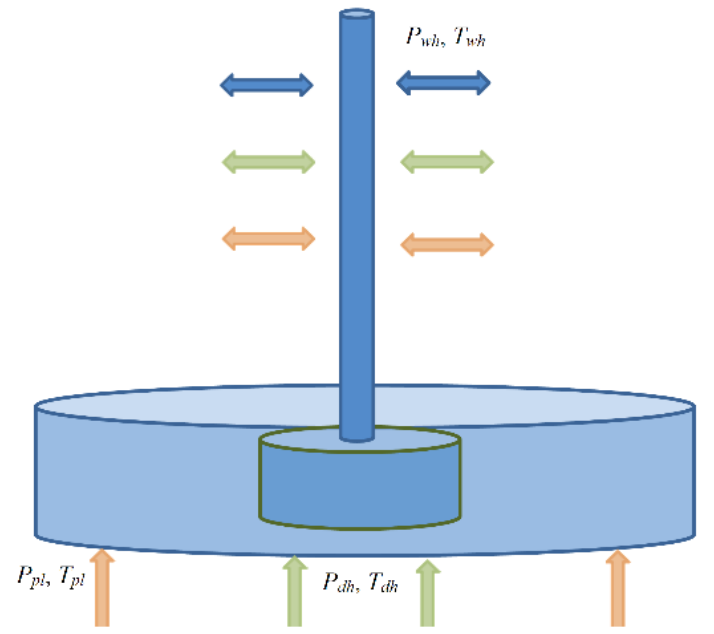

Figure 1. Thermal medium-fluid flow diagram and heat exchange with rocks in terms of the seam-wellbottom zone-well system

It is understood from Fig. 1 that temperatures of the adjoining rocks vary which is marked by different colours of the arrows. In the neighbourhood of the well bottom, temperature is lower to compare with that in the seam; however, along the lift rock temperature decreases bottom-up.

Oil string-rock mass heat transfer can be described with the help of following equations of nonisothermal vertical lifting as well as longitudinal heat exchange [4]:

$$
\begin{aligned}
& P_{w h}=\sqrt{P_{b h}{ }^{2} \cdot e^{\frac{2 \cdot g \cdot H}{Z \cdot R \cdot T_{0} \cdot \phi_{t}\left(T_{b h}, T_{w h}, T_{o}\right)}}}- \\
& -\frac{8 \cdot M q^{2} \cdot \lambda\left(k_{e}, \operatorname{Re}, D\right) \cdot z^{2} \cdot R^{2} \cdot T_{o}{ }^{2} \cdot \phi_{t}\left(T_{b h}, T_{w h}, T_{o}\right)}{D^{5} \cdot \pi^{2} \cdot g} \times \\
& \times\left(1-e^{\frac{2 \cdot g \cdot H}{Z \cdot R \cdot T_{0} \cdot \phi_{t}\left(T_{b h}, T_{w h}, T_{o}\right)}}\right) ; \\
& M_{q} \cdot C_{p}\left(P_{a v}, T_{a v}, M\right) \cdot\left(T_{w h}-T_{b h}-\left(P_{b h}-P_{w h}\right) .\right. \\
& \left.\times D_{j}\left(P_{a v}, T_{a v}, M\right)\right)=K_{t} \cdot \pi \cdot D \cdot \int_{0}^{H}\left(T_{0}(x)-T(x)\right) d x,
\end{aligned}
$$

where:

$$
\phi_{t}\left(T_{b h}, T_{w h}, T_{o}\right)=\left(1+\frac{T_{b h}-T_{w h}}{T_{o} \cdot \ln \left(\frac{T_{b h}-T_{o}}{T_{w h}-T_{o}}\right)}\right)-\text { temperature }
$$

correction by Shukhov;

$$
\begin{aligned}
& P_{a v}=\frac{2}{3} \cdot\left(P_{b h}+\frac{P_{w h}^{2}}{P_{b h}+P_{w h}}\right)= \\
& =\rho(P, T, M) \cdot z(P, T, M) \cdot R \cdot T_{o} \cdot \phi_{t}= \\
& =\rho(P, T, M) \cdot z(P, T, M) \cdot R \cdot T_{a v}
\end{aligned}
$$
- average pressure value;

$T_{a v}=T_{o} \cdot \phi$ - average temperature value;

$\lambda\left(k_{e}, \operatorname{Re}, D\right)$ - hydraulic resistance.

Set of equations (1-8) describes a closed system; it is applied to calculate output of a gas condensate well in terms of the essentially nonisothermal process of radial inflow of the 
fluid, produced from the seam, and its lifting through the well string [5], [8]. Among other things, the abovementioned modernization is characterized by following disadvantages: the assumption of $K_{t}$ invariance along a string and/or along the productive formation; the assumption that $\Delta T_{h e}=0$; the assumption of $D_{j}$ invariance from the seam boundary to the wellhead; and ignorance of thermal exchange variations at different depths [9].

Either complete correction of the modern research or its partial correction is the topical problem which solving will result in the improved modeling of accuracy of gas condensate well operation, and forecasting of heat production as well as gas condensate mixture.

The purpose is to substantiate theoretically the methodological foundations to forecast production of geothermal resources of gas condensate deposits in terms of the seamwellbottom zone-well system. In this context, dynamic processes of heat transfer and thermal diffusion should be involved as well as fluid expansion coefficient in terms of nonadiabatic processes, effect of mean integral environmental temperature on the heat transfer, changes in molar mass of the produced fluid during the whole period of the well operation, and a process of the productive formation cooling at the initial stage of the well operation (months-years).

To achieve the purpose, following research problems have been formulated:

- to develop mathematical model of nonisothermal radial inflow and lifting (i.e. evacuation using internal PT cavity) of the produced gaseous mixture (i.e. geothermal fluid) of the well taking into consideration dynamic coefficient of heat transfer and thermal diffusion being determined by means of a geothermal gradient in terms of a depth and/or the productive formation radius, and rock-fluid temperature difference under the working conditions; to involve fluid expansion coefficient in terms of nonadiabatic process, effect of mean integral environmental temperature on the heat transfer, changes in molar mass of the produced fluid during the whole period of the well operation, and a process of the productive formation cooling at the initial stage of the well operation (months-years);

- to carry out comparative analysis of results of the thermal medium modeling within a geothermal well of gas condensate well according to the response functions: wellhead fluid; fluid mass consumption through the well; output of the well in terms of such variable parameters as geostatic pressure within the well and temperature; rocks-fluid heat transfer coefficient; and molar mass of the fluid being lifted;

- to perform full-scale studies intended to measure formation temperatures as well as wellhead ones, and compare them with those obtained analytically (years of 2006-2015).

\section{Research methods}

The research methods are to analyze comparatively the variants of gas condensate fluid production: taking into consideration nonadiabatic expansion effect and variable heat exchange along the mixture migration. In this context, thermobaric parameters of the produced hydrocarbon mixture and the well output are calculated; long-term forecasting of the model is performed.

Structure of the research and its order involve: analysis of energy component of geothermal resource (i.e. heat) production as well as thermodynamic interaction between fluidsaturated rocks of the productive formation and the produced heat-conserving fluid; analysis of expansion effect of gaseous components of hydrocarbon fluids; and analysis of changes in thermodynamic parameters in the process of forecasting of a single development of geothermal deposit on the basis of one gas condensate deposit.

Forecasting method of energy resource production from oil-gas deposits and numerical methods of fluid dynamics have been applied. A system of nonlinear equations of the developed mathematical model was solved using RungeKutta $4^{\text {th }}$ order method, and Quazi-Newton method have been applied.

\section{Development of the mathematical model}

Equation for pseudocritical parameters of the produced hydrocarbon gaseous mixture has been developed taking into consideration the assumption of minor amounts of nitrogen and carbon (less than 2 mass \%). If content of the gases within the produced fluid is significant, then more complicated analytics should be involved [10], [11]; however, the research applies following approximation:

$$
\begin{aligned}
& T_{p c}=88.25 \cdot\left(0.9915+1.759 \cdot \frac{M}{24.05525 \cdot z_{s t}}\right) ; \\
& P_{p c}=2.9585 \cdot\left(1.608+0.05994 \cdot \frac{M}{24.05525 \cdot z_{s t}}\right) .
\end{aligned}
$$

Joule-Thompson effect was calculated relying upon the assumption that methane concentration within the well product is more than $95 \%$ and relative density is $\Delta \sim 0.6$. After introduction of expansion effect $K_{a}$ (being possible in terms of natural gas humidity increase) and use of (5)-(6) formulas as well as consideration of [7] calculations, both working equation and comparative equation of the research have been obtained:

$$
\begin{aligned}
& D_{j}(P, T, M)=\frac{K_{a}}{C_{p}(P, T, M) \cdot 10^{-3}}\left(\frac{0.98 \cdot 10^{6}}{T^{2}}-\frac{1}{\rho(P, T, M)}\right)=K_{a}\left(\left(24.96-20.3 \cdot \frac{T}{T_{p c}}+4.57 \cdot\left(\frac{T}{T_{p c}}\right)^{2}\right)+\right. \\
& +\left(5.66-19.92 \cdot \frac{T}{T_{p c}}+16.89 \cdot\left(\frac{T}{T_{p c}}\right)^{2}\right) \cdot \frac{P}{P_{p c}}+\left(-4.66+14.58 \cdot \frac{T}{T_{p c}}+13.39 \cdot\left(\frac{T}{T_{p c}}\right)^{2}\right) \times \\
& \left.\times\left(\frac{P}{P_{p c}}\right)^{2}+\left(0.568-2 \cdot \frac{T}{T_{p c}}+1.79 \cdot\left(\frac{T}{T_{p c}}\right)^{2}\right) \cdot\left(\frac{P}{P_{p c}}\right)^{3}\right) .
\end{aligned}
$$

(9)-(11) formulas were applied universally to calculate the fluid inflow to the wellbottom and gas condensate mix- ture evacuation through the well PT. Model of the formulas was selected for nonadiabatic expansion of the fluid migra- 
tion according to a concept applied for natural gas migration with heat exchange via depth oil-and-gas pipelines [12], [13]. The authors added $K_{a}$ parameter taking into consideration the process deviations from adiabatic conditions.

Hydraulic resistance within production tubing or within any other tubing of $\lambda$ well is a function of Re number, temperature, and other standard parameters and design parameters [11]; hence, in the context of the research of nonisothermal lifting of hydrocarbon mixture, the working functional dependence $\lambda\left(P, T, M, M_{q}, D, k_{e}\right)$ has been developed and applied for equation (7). The dependence is based upon Colebrook-White equation and S. Borisov and I. Khodanovich studies [12] (instead of the abovementioned functional dependence $\left.\lambda\left(k_{e}, \operatorname{Re}, D\right)\right)$ :

$$
\begin{aligned}
& \frac{1}{\sqrt{\lambda\left(P, T, M, M_{q}, D, k_{e}\right)}}= \\
& =-2 \cdot \lg \left(\frac{k_{e}}{3.7 \cdot D}+\frac{2.51 \cdot \mu(P, T, M) \cdot \pi \cdot D}{4 \cdot M_{q} \cdot \sqrt{\lambda\left(P, T, M, M_{q}, D, k_{e}\right)}}\right),
\end{aligned}
$$

since $\operatorname{Re}\left(P, T, M, M_{q}, D\right)=\frac{4 \cdot M_{q}}{\mu(P, T, M) \cdot \pi \cdot D}$.

No one of basic traditional methods consider $K_{t}$ coefficient as a variable one along a productive string of a well and geothermal reservoir radius. The value was recorded at one mean level. Alternatively, in terms of the developed and improved model, we apply $K_{t}$ dependence upon longitudinal thermobaric conditions according to Vlasov equation and [2], [13] recommendations of the type:

$$
\begin{aligned}
& C_{p}(P, T)=R\left(\left(4.437-1.015 \cdot \frac{T}{T_{p c}}+0.59 \cdot\left(\frac{T}{T_{p c}}\right)^{2}\right)+\left(3.29-11.37 \cdot \frac{T}{T_{p c}}+10.9 \cdot\left(\frac{T}{T_{p c}}\right)^{2}\right) \cdot \frac{P}{P_{p c}}+\right. \\
& \left.+\left(3.23-16.57 \cdot \frac{T}{T_{p c}}+25.48 \cdot\left(\frac{T}{T_{p c}}\right)^{2}-11.28 \cdot\left(\frac{T}{T_{p c}}\right)^{3}\right) \cdot\left(\frac{P}{P_{p c}}\right)^{2}+\left(-0.214+0.908 \cdot \frac{T}{T_{p c}}-0.967 \cdot\left(\frac{T}{T_{p c}}\right)^{2}\right) \cdot\left(\frac{P}{P_{p c}}\right)^{3}\right) .
\end{aligned}
$$

It is unacceptable to consider a temperature as invariable value in a process of a rocks-produced fluid heat exchange within a bottom-hole formation zones in the localized wall packing (Fig. 1) results in the increased depression in the inflow area. Following specified dependence has been applied instead of (2):

$$
\begin{aligned}
& M_{q} \cdot C_{p}\left(P_{r a v}, T_{r a v}, M\right) \cdot\left(T_{b h}-T_{p l}+\left(P_{b h}-P_{p l}\right) \times\right. \\
& \left.\times D_{j}\left(P_{r a v}, T_{r a v}, M\right)\right)=2 \pi \times \\
& \times \int_{0}^{R_{k}}\left(K_{t}(x) \cdot x \cdot\left(T_{p l}(x)-T(x)\right)\right) d x .
\end{aligned}
$$

In terms of the represented form, energy equations for the seam (16) and the production string maintain thermal diffusion coefficients; integral structure within the right member of the equation factors into the consideration of a mean integral temperature value of the fluid and rocks properly.

Use of the proposed additional functional dependences and (9)-(16) equations in the system of the known (1), (3-4), and (7) equations helped evaluate effect of actual $K_{t}\left(T_{o}(x)\right)$

$$
K_{t}\left(T_{o}(x)\right)=\frac{K_{t o}}{1+\beta_{a} \cdot T_{o}(x)} .
$$

In depth, rock temperature has static distribution; however, temperature of a mobile gas condensate mixture within a well as well as a production string is characterized by the dynamic depth temperature distribution. Consequently, fluidrocks heat transfer becomes of a dynamic nature in terms of a depth and a radius. After a certain period the well was started up (i.e. when transition processes were over), dynamic distribution of the heat transmission parameters is described with the help of a functional dependence in terms of the lift length (i.e. in terms of the depth) which is proposed to take into consideration in the process of calculation of forecasting well output. Consideration of dependence of overall heat transfer coefficient $K_{t}$ upon a mean integral temperature value transforms it into the analogue of overall coefficient of thermal diffusion $K_{t}(T(x))$ which is a determinative one for intensive heat migration between rocks and fluid being lifted.

Rock temperature varies in terms of each certain well depth; thus, equation (8) moves to the following:

$$
\begin{aligned}
& M_{q} \cdot C_{p}\left(P_{a v}, T_{a v}\right) \cdot\left(T_{w h}-T_{b h}-\right. \\
& -\left(P_{b h}-P_{w h}\right) \times D_{j}\left(P_{a v}, T_{a v}, M\right)= \\
& =\pi \cdot D \cdot \int_{0}^{H}\left(K_{t}(x) \frac{\left(T_{0}(x)-T(x)\right)}{1+\beta_{a} \cdot T_{o}(x)}\right) d x
\end{aligned}
$$

$C_{p}$ was determined according to a simple formula depending on pressure and temperature as well as on changes in molar mass of hydrocarbon mixture $M$ relying upon the abovementioned dependences $(9-10)$ :

distribution on the well. Modeling in terms of initial equation system (1)-(8) (with constant average values $K_{t}=1.5 \mathrm{~W} /\left(\mathrm{m}^{2} \mathrm{~K}\right)-$ const and $D_{j}=2.5 \mathrm{~K} / \mathrm{MPa}-$ const $)$ applied to determine a system of all the parameters in the first approximation [14] deals with the mathematical methods intended to solve systems of nonlinear equations. At different depths of a well string advance, rock pressure may be taken up in accordance with the thermal gradients (i.e. those, identified while drilling), if only rocks-hydrocarbon mixture within a well heat exchange is not available.

At the same time, we believe that wall packing effects within a well bottom zone should be taken into consideration using (16). After certain period of production of fluid, heated by bottom levels, the seam-well system demonstrates a balance of longitudinal dynamic pressures as well as longitudinal dynamic temperatures. Among other things, the temperatures will depend upon the fluid temperature within the productive formation, and upon heat-exchange processes and expansion from the depths to a surface, namely through a calmatation area in the neighbourhood of the well bottom [15]. 


\section{Results and discussions}

Practical value of the developed mathematical model may be especially notable while applying popular thermobaric methods intensifying hydrocarbon production, intensification with the use of foaming reagents, and geothermal energy production. The results of stage one of the research were represented at the conference [8]. Figure 2 demonstrates dependence of the well output upon molar mass of the produced fluid within the productive formation for a series of different values of dynamic thermal conductivity from the fluid (inside the well string) to adjoining rocks. It is understood from Figure 2 that well output depends heavily upon thermal conductivity. Changes in thermal conductivity from 1 up to $1.5 \mathrm{~W} / \mathrm{m}^{2} \mathrm{~K}$ factor into $15-20 \%$ change in $M_{q}$ output as well as in $10-15 \%$ temperature change within a wellhead $T_{w h}$.

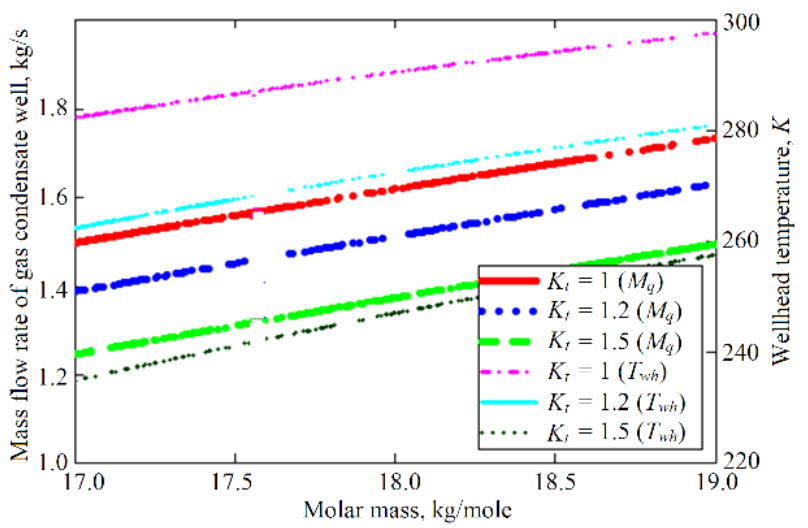

Figure 2. Dependence of mass flow $M_{q}$ upon molar mass $M$ and dependence of wellhead temperature $T_{w h}$ upon molar mass $M$ taking into consideration discrete changes in rock thermal conductivity $K_{t}$ within $1-1.5 \mathrm{~W} / \mathrm{m}^{2} \mathrm{~K}$ range (it is intended for $1,1.2$, and $1.5 \mathrm{~W} / \mathrm{m}^{2} \mathrm{~K}$ values)

It is possible to state that in the context of the considered conditions of Lanivske deposit, wellhead temperature and mass output decrease for greater values of thermal conductivity resulting in the multiplicative effect of the decreased heat production. It has been determined that the total error (relative to the proposed specified method) may achieve $20-30 \%$ while calculating heat output of gas condensate well if isothermic equation by Adamov is applied as well as a two-term equation of fluid heat inflow to a well bottomhole (i.e. thermal medium lifting) under the conditions of use of thermobaric methods to intensify a well output. The abovementioned is explained by the fact that traditional adaptation of $\mathrm{A}$ and $\mathrm{B}$ parameters as well as decrease in the error need time and resources for the well studies in the context of different operational modes. However, the trouble is that time and resources are the common deficit at an industrial enterprise which prevents from the maximum research quality control [16]. Changes in formation temperature to $30-40^{\circ}$ factor into 1.5 times change in thermal conductivity which may result in up to $30 \%$ changes in heat inflow. Formula (14) explains that heat production is proportional to thermal-medium fluid $M_{q}$ multiplied by the difference of wellhead temperatures $T_{w h .}$ Figure 2 also demonstrates that $2 \mathrm{~kg} / \mathrm{mol}$ change (i.e. $5-7 \%$ of initial one) in molar mass of gaseous fluid, being a thermal medium, results in $12-14 \%$ change in the mass output.

Figure 3 shows that the temperature effect on the output is less significant for the minimum formation pressure being
$20 \mathrm{MPa}$; however, in terms of $40^{\circ}$ pressure difference and $24 \mathrm{MPa}$ pressure, it is almost $20 \%$. Wellhead temperature correlates with the productive formation temperature (Fig. 3) confirming adequacy of the modeling.

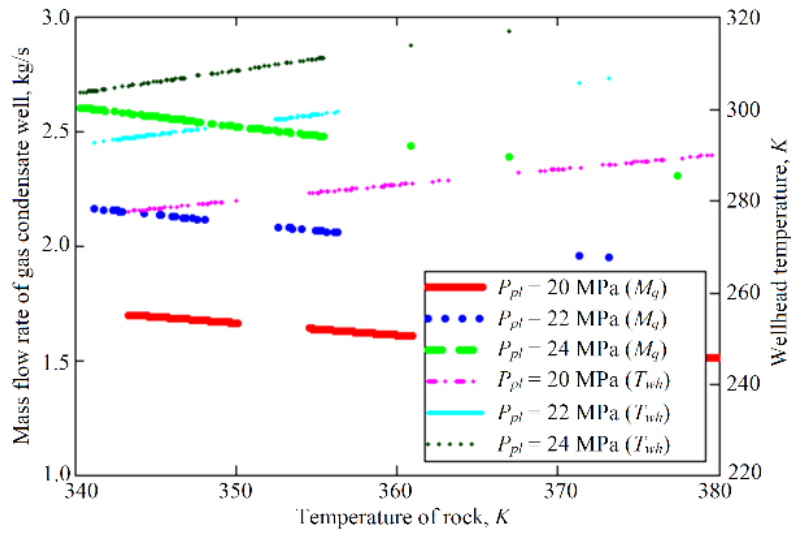

Figure 3. Dependence of mass flow $M_{q}$ upon a formation temperature $T_{p l}$ and dependence of wellhead temperature $T_{w h}$ upon formation temperatures $T_{p l} M_{q}\left(T_{p l}\right)$ and $T_{w h}\left(T_{p l}\right)$ taking into consideration discrete changes in formation pressures $P_{p l}$ within 20-24 MPa range (it is intended for: 20, 22, and 24 MPa values)

Mathcad 15 software was applied for the modeling which made it possible to verify the results of the calculations and short-term forecasts under office conditions and in the full-scale using compact gadgets with operating system Windows 10 .

Figures 4 and 5 demonstrate long-term forecasting of temperatures and pressures within the productive formation and wellhead of Lanivske gas condensate deposit (GCD).

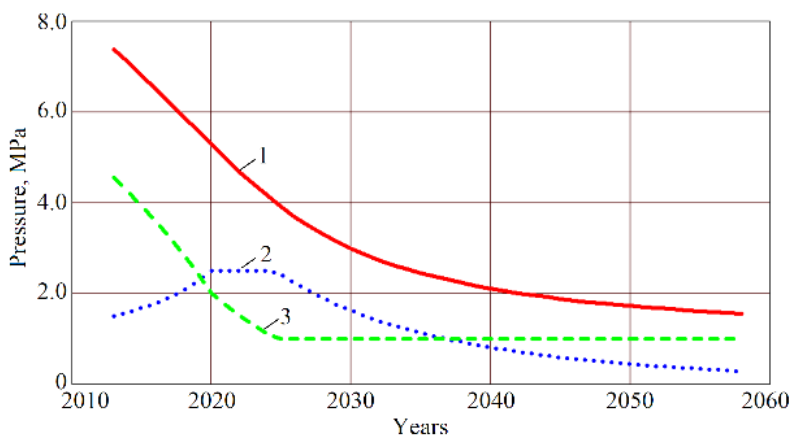

Figure 4. The predicted pressures within the productive formation and a wellhead of Lanivske gas condensate deposit for 50 years: 1-formation pressure; 2-differential pressure (formation pressure - bottomhole pressure); 3 -wellhead pressure

During the forecasting period, formation pressure decreases together with the deposit depletion (Fig. 4). The graph shows three basic modes of the deposit development: with constant well output to 2020; with constant differential pressure up to 2025; and with wellhead pressure limitation (i.e. with the specified backpressure setting) up to 2060. It is understood from Figure 5 that wellhead temperatures vary to 500 in time. Similar variations in wellhead temperatures happen in terms of momentary output changes which may be a result of wellbottom area calmatation. Figure 6 explains output of a thermal medium bringing geothermal energy to the surface during the whole predicted period. 


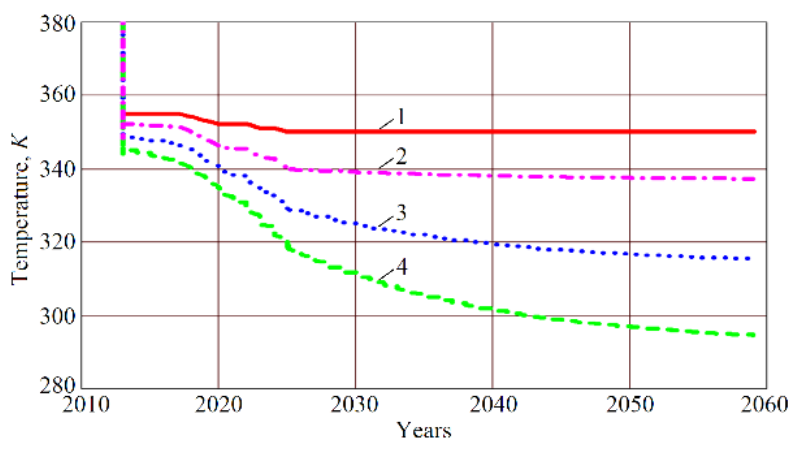

Figure 5. The predicted temperatures within the productive formation, within a bottomhole, and within a wellhead of Lanivske gas condensate deposit for 50 years: 1 - formation temperature; 2 -fluid temperature within a bottomhole; 3-fluid temperature along the well shaft; 4 -fluid temperature within the wellhead

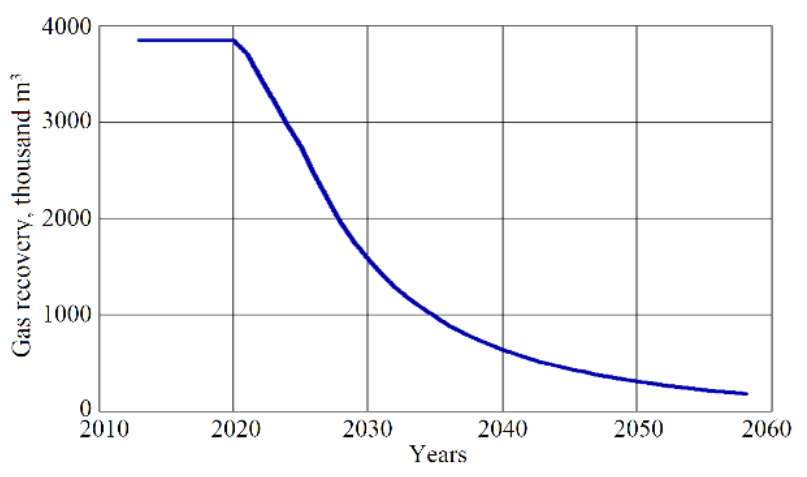

Figure 6. The predicted annual output of gaseous fluid within Lanivske GCD lifting geothermal energy to the surface (thousands of standard cubic meters)

To enable representation of complete information concerning operating conditions of a well while producing thermal medium fluid and its further analysis, full forecasting of a deposit, involving seven wells, have been performed (Figs. 4-6). Heat was produced with gas condensate thermal medium forecasting. During the prognosis period, output of the series of wells experienced more than ten-fold decrease (Fig. 6) which helped expand the research range in addition to the analysis of thermal gas dynamic processes within the seam as well as within production tubing of the well.

The checking procedure has supported suitability of the calculations for their implementation under industrial conditions which also excluded the necessity to apply modeling software being more demanding for computing facilities.

It should be noted that solution of the set of nonlinear equations, using the abovementioned techniques of a variable metric (i.e. Quazi-Newton methods), has its own specific features. To compare with a cumbersome Newton method, the techniques are somehow simplified and cannot give any solutions within each intermediate point of ranges of the parameters; and curves have gaps and considerable breaks (Figs. 2 and 3). However, they demonstrate tendencies and potential to compare the functions under study [14]. In addition to the modeling experiment with the use of mathematical tools (1-16), full-scale studies were carried out on the basis of Lanivske gas condensate deposit. In this context, wellhead temperatures of the produced gas fluid were measured for the period of 2006-2015. Table 1 demonstrates the comparison results of modeling data, and full-scale data in terms of wells
$3,5,8,23,25,27,103,104,202,203,204,205,300$, and 301 . It should be mentioned that the wells penetrate productive levels of one thick formation which united in gas hydrodynamic manner the levels after numerous use of fracturing fluids. Actually, formation fluids from all the wells flew from one underground reservoir with 500-600 thickness within the arching with a formation pressure and temperature for the measuring period.

Table 1. Analytical wellhead temperatures of gas wells within Lanivske deposit, and actual ones

\begin{tabular}{cccccc}
\hline Well & $\begin{array}{c}\text { Actual } \\
\text { temperature } \\
\text { within the } \\
\text { wellhead, K }\end{array}$ & $\begin{array}{c}\text { Date } \\
\text { of the mea- } \\
\text { surement }\end{array}$ & $\begin{array}{c}\text { Formation } \\
\text { temperature, } \\
\text { K }\end{array}$ & $\begin{array}{c}\text { Depth, } \\
\mathrm{m}\end{array}$ & $\begin{array}{c}\text { Analytical } \\
\text { temperature } \\
\text { within the } \\
\text { wellhead, K }\end{array}$ \\
\hline 3 & 291 & 22.04 .2015 & 347 & 3388 & 290 \\
5 & 295 & 24.11 .2008 & 355 & 3700 & 293 \\
8 & 289 & 06.11 .2008 & 344 & 3354 & 290 \\
23 & 289 & 29.06 .2010 & 348 & 3650 & 286 \\
25 & 290 & 28.07 .2011 & 350 & 3787 & 288 \\
27 & 290 & 16.07 .2006 & 351 & 3733 & 289 \\
103 & 292 & 26.03 .2009 & 349 & 3276 & 291 \\
104 & 295 & 14.02 .2008 & 355 & 3724 & 293 \\
202 & 286 & 25.10 .2011 & 345 & 3359 & 284 \\
203 & 290 & 08.04 .2011 & 346 & 3386 & 288 \\
204 & 291 & 18.01 .2011 & 346 & 3500 & 290 \\
205 & 288 & 27.04 .2012 & 345 & 3510 & 286 \\
300 & 294 & 31.03 .2008 & 356 & 3903 & 291 \\
301 & 290 & 22.06 .2011 & 352 & 3710 & 287 \\
\hline
\end{tabular}

Table 1 clarifies that despite significant difference in the penetration depths of the formations (3354-3909 m), actual wellhead temperatures are relatively close (288-295 K) which can be understood sufficiently by insignificant outputs of the development gas wells. In the context of such outputs, wellhead temperatures near high natural geothermal values since in the process of lifting within oil string, natural gas gives up significant share of the heat [17].

Comparative analysis of actual wellhead temperatures and their predicted values show convergence of the modeling data and the basic ones within 2-4\% of relative accuracy verifying high adequacy of the developed mathematical model.

Two-stage approximation may be proposed to calculate hydrocarbon lifting for industrial forecasting of fluid and geothermal heat production. It is expedient to apply the accepted techniques at stage one. The proposed mathematical dependences (9)-(16) are more relevant for stage two.

\section{Conclusions}

Mathematical model of nonisothermal radial inflow and the produced well gaseous mixture has been developed involving dynamic coefficient of heat conductivity and thermal diffusion; coefficient of fluid expansion in terms of nonadiabatic process; influence of a mean integral environmental temperature on the efficiency of heat transmission; changes in molar mass of the produced fluid during a well operation; and cooling process of the productive formation during the initial stage of the well operation (months-years). In-depth consideration of actual changes in thermal conductivity of rocks depending upon their temperatures (well established values in dynamics) as well as changes in temperature of the produced fluid in terms of extension within a wellbottom area, and within the well shaft makes it possible to specify forecast of the well output by $10-15 \%$; and amounts of the produced heat may be specified up to $20-30 \%$. 
Comparative analysis of the modeling results of thermal medium lifting within a geothermal well of a gas condensate deposit has been performed according to following response function: fluid temperature within a wellhead; mass fluid flow via the well; and the well output.

It has been determined that:

- both wellhead temperature and mass fluid flow depend in the direct proportion upon a formation pressure;

- mass fluid flow via a well depends inversely upon a formation temperature;

- both mass fluid flow and wellhead temperature depend in the direct proportion on the molar mass; they both depend in inverse proportion on the rocks-fluid heat transfer coefficient;

- in the context of long-term forecasting, the well output decreases along with the formation pressure decrease (i.e. the deposit depletion);

- difference between the productive formation temperature and fluid temperature within a wellhead increases from 10 to $45^{\circ} \mathrm{C}$ along with Lanivske deposit depletion during 50 years of its operation;

- exponential decrease in the formation pressure, output, and wellhead temperature are observed in the process of the well operation: according to the forecast, 50-year operational period will imply four-times decrease in the formation temperature, and well head temperature will decrease by $15-17 \%$, i.e. by $50^{\circ} \mathrm{C}$.

During 2006-2015, formation temperatures and wellhead temperatures of 14 different wells within Lanivske deposit were measured. Comparative analysis of actual wellhead temperatures and their predicted values show convergence of the modeling data and the basic ones within $2-4 \%$ of relative accuracy verifying high adequacy of the developed mathematical model.

Hence, adequate mathematical model of nonisothermal radial inflow and the produced well gaseous mixture has been developed involving adiabatic and nonadiabatic nature of processes within a formation area, dynamic coefficients of extension, heat conductivity, and thermal diffusion. Further research is topical in the field of the intensified production of geothermal resources from the depleted oil and gas deposits where it is possible to apply hydraulic fracturing techniques, physiochemical and bacteriological methods, and processes intended to develop thick deposits of thermal media [18]-[22].

\section{Acknowledgements}

The authors are grateful to Ukrgazvydobuvannya PJSC for the opportunity to obtain both empiric materials and parametric data concerning gas condensate wells of Lanivske GCD.

\section{References}

[1] Azin, R., Sedaghati, H., Fatehi, R., Osfouri, S., \& Sakhaei, Z. (2018). Production assessment of low production rate of well in a supergiant gas condensate reservoir: applicatio n of an integrated strategy. Journal of Petroleum Exploration and Production Technology, 9(1), 543-560. https://doi.org/10.1007/s13202-018-0491-y

[2] Guo, B., Li, J., Song, J., \& Li, G. (2017). Mathematical modeling of heat transfer in counter-current multiphase flow found in gas-drilling systems with formation fluid influx. Petroleum Science, 14(4), 711-719. https://doi.org/10.1007/s12182-017-0164-3

[3] Sharafutdinov, R.F., Kanafin, I.V., Khabirov, T.R., \& Nizaeva, I.G. (2017). Numerical research of temperature field in "well - formation" system with oil degassing. Tyumen State University Herald. Physical and Mathematical Modeling. Oil, Gas, Energy, 3(2), 8-20. https://doi.org/10.21684/2411-7978-2017-3-2-8-20

[4] Kiaghadi, A., Sobel, R.S., \& Rifai, H.S. (2017). Modeling geothermal energy efficiency from abandoned oil and gas wells to desalinate produced water. Desalination, (414), 51-62. https://doi.org/10.1016/j.desal.2017.03.024

[5] Kutia, M., Fyk, M., Kravchenko, O., Palis, S., \& Fyk, I. (2016) Improvement of technological-mathematical model for the mediumterm prediction of the work of a gas condensate field. EasternEuropean Journal of Enterprise Technologies, 5(8(83)), 40-48. https://doi.org/10.15587/1729-4061.2016.80073

[6] Fyk, M., Palis, S., \& Kovalchuk, J. (2016). Gas well production enhancement on the application of innovative structural and thermal insulation nano-coatings. Visnyk of V.N. Karazin Kharkiv National University, Series “Geology. Geography. Ecology”, (45), 80-85.

[7] MahmoodMoshfeghian. (2009). Variation of natural gas heat capacity with temperature, pressure, and relative density. Posted on July 1, 2009 at 10:23 pm

[8] Al-Sutan, M. (2019). The effect of the change in well thermobaric properties on the flow rate from exhausted gas-condansate reservoir. Problems of Geoengineering and Underground Urbanism, 1-2.

[9] Fyk, M., Biletskyi, V., Fyk, I., Bondarenko, V., \& Al-Sultan, M.B. (2019). Improvement of an engineering procedure for calculating the non-isothermal transportation of a gas-liquid mixture. EasternEuropean Journal of Enterprise Technologies, 3(5(99)), 51-60. https://doi.org/10.15587/1729-4061.2019.167198

[10] Lurie, M.V. (2008). Modeling of oil product and gas pipeline transportation. Weinheim, Germany: WILEY-VCH Verlag GmbH \& Co. KGaA. https://doi.org/10.1002/9783527626199

[11] Kabir, C.S., Hasan, A.R., Kouba, G.E., \& Ameen, M. (1996). Determining circulating fluid temperature in drilling, workover, and well control operations. SPE Drilling \& Completion, 11(02), 74-79. https://doi.org/10.2118/24581-pa

[12] Li, F., Xu, T., Li, S., Feng, B., Jia, X., Feng, G., \& Jiang, Z. (2019). Assessment of energy production in the deep carbonate geothermal reservoir by wellbore-reservoir integrated fluid and heat transport modeling. Geofluids, (2019), 1-18. https://doi.org/10.1155/2019/8573182

[13] Rzaev, A., Rasulov, S., Pashaev, F., \& Salii, M. (2017). Features of distribution of temperature along the length of oil pipeline. Perm Journal of Petroleum and Mining Engineering, 16(2), 158-163. https://doi.org/10.15593/2224-9923/2017.2.6

[14] Kujawa, T., Nowak, W., \& Stachel, A.A. (2005). Analysis of the exploitation of existing deep production wells for acquiring geothermal energy. Journal of Engineering Physics and Thermophysics, 78(1), 127-135. https://doi.org/10.1007/s10891-005-0038-1

[15] Shendrik, O., Fyk, M., Biletskyi, V., Kryvulia, S., \& Donskyi, D. (2019). Energy-saving intensification of gas-condensate field production in the east of Ukraine using foaming reagents. Mining of Mineral Deposits, 13(2), 82-90. https://doi.org/10.33271/mining13.02.082

[16] Fyk, M., Biletskyi, V., \& Abbud, M. (2018). Resource evaluation of geothermal power plant under the conditions of carboniferous deposits usage in the Dnipro-Donetsk depression. E3S Web of Conferences, (60), 00006. https://doi.org/10.1051/e3sconf/20186000006

[17] Fyk, M., Fyk, I., Biletsky, V., Oliynyk, M., Kovalchuk, Y., Hnieushev, V., \& Shapchenko, Y. (2018). Theoretical and applied aspects of using a thermal pump effect in gas pipeline systems. EasternEuropean Journal of Enterprise Technologies, 1(8(91)), 39-48. https://doi.org/10.15587/1729-4061.2018.121667

[18] Alimonti, C., \& Soldo, E. (2016). Study of geothermal power generation from a very deep oil well with a wellbore heat exchanger. Renewable Energy, (86), 292-301. https://doi.org/10.1016/j.renene.2015.08.031

[19] Jung, R., Hassanzadegan, A., \& Tischner, T. (2019). Determination of hydraulic properties of a large self-propped hydraulic fracture in the geothermal research borehole Horstberg Z1 in the Northwest German Basin. Geofluids, (2019), 1-13. https://doi.org/10.1155/2019/3508906

[20] Mehmood, A., Yao, J., Fan, D., Bongole, K., Liu, J., \& Zhang, X. (2019). Potential for heat production by retrofitting abandoned gas wells into geothermal wells. PLOS ONE, 14(8), e0220128. https://doi.org/10.1371/journal.pone.0220128

[21] Breede, K., Dzebisashvili, K., Liu, X., \& Falcone, G. (2013). A systematic review of enhanced (or engineered) geothermal systems: past, present and future. Geothermal Energy, 1(1). https://doi.org/10.1186/2195-9706-1-4

[22] Lei, Z., Zhang, Y., Hu, Z., Li, L., Zhang, S., Fu, L., \& Yue, G. (2019). Application of water fracturing in geothermal energy mining: insights from experimental investigations. Energies, 12(11), 2138. https://doi.org/10.3390/en12112138 


\section{Моделювання ліфтингу теплоносія в геотермальній свердловині газоконденсатного родовища}

\section{М. Фик, В. Білецький, М. Аббуд, М. Аль-Султан, М. Аббуд, Х. Абдуллатіф, Є. Шапченко}

Мета. Розробка математичної моделі неізотермічного притоку та ліфтингу видобувної газоподібної суміші (геотермального флюїду) свердловини з урахуванням динамічного коефіцієнта теплопровідності та теплової дифузії, коефіцієнта дроселювання флюїду при неадіабатичному процесі, впливу середньоінтегральної температури середовища на ефективність теплопередачі, зміни молярної маси флюїду протягом терміну експлуатації свердловини, процесу охолодження продуктивного пласта на первинному етапі (місяці - роки) експлуатації.

Методика. Застосовано метод матеріально-енергетичного балансу потоків флюїду і тепла у продуктивному пласті та свердловині, прогнозування видобутку геотермального флюїду, чисельні методи термогазодинаміки рідини, методи Ранге-Кута четвертого порядку та Квазіньютонівський метод вирішення нелінійних рівнянь.

Результати. Показано, що термічний градієнт гірських порід та теплообмін “теплоносій - порода” змінюється залежно від режиму роботи покладу та свердловини. Це обумовлюється впливом температури, перепаду температури на вологість, в’язкість, стисливість, інші властивості порід, які визначають ефективність теплової дифузії та коефіцієнт теплообміну між флюїдом та гірськими породами.

Наукова новизна. Розроблено уточнені рівняння теплового балансу енергії при радіальній фільтрації та ліфтингу продукції свердловини, які вигідно відрізняються від застосовуваних в сучасних методах розрахунку введенням коефіцієнта дроселювання флюїду в пласті при неадіабатичному процесі, врахуванням впливу середньоінтегральної температури середовища на ефективність теплопередачі (відомі методики враховують середньогеометричну температуру пласта). Враховується фактична зміна молярної маси видобувного геотермального флюїду протягом терміну експлуатації свердловини (до 50 років). Термогазодинамічну модель “свердловинний притік - ліфтинг” вдосконалено врахуванням перехідного процесу охолодження продуктивного пласта на первинному етапі (місяці - роки) видобування геотермального флюїду.

Практична значимість. Розроблена математична модель дозволяє уточнити розрахунок дебіту свердловини на 10-15\%. Розроблена модель відносно базових методик дозволяє в умовах термобаричної інтенсифікації видобутку флюїду і бінарних технологій видобутку “флюїд - геотепло” уточнювати на 20-30\% видобування тепла газоконденсатною свердловиною. Математична модель уточнює гирлові температури природного газу.

Ключові слова: дебіт геотермального флюїду, термічний градієнт, гірська порода, параметричне температурне поле, коефіиієнт теплообміну, ефект Джоуля-Томсона

\section{Моделирование лифтинга теплоносителя в геотермальной скважине газоконденсатного месторождения}

\section{М. Фык, В. Белецкий, М. Абуд, М. Аль-Султан, М. Абуд, Х. Абдулатиф, Е. Шапченко}

Цель. Разработка математической модели неизотермического притока и лифтинга добывающей газообразной смеси (геотермального флюида) скважины с учетом динамического коэффициента теплопроводности и тепловой диффузии, коэффициента дросселирования флюида при неадиабатическом процессе, влияния среднеинтегральной температуры среды на эффективность теплопередачи, изменения молярной массы флюида в течение срока эксплуатации скважины, процесса охлаждения продуктивного пласта на первоначальном этапе (месяцы - годы) эксплуатации.

Методика. Применен метод материально-энергетического баланса потоков флюида и тепла в продуктивном пласте и скважине, прогнозирования добычи геотермального флюида, численные методы термогазодинамики жидкости, методы Ранге-Кута четвертого порядка и квазиньютоновского метода решения нелинейных уравнений.

Результаты. Показано, что термический градиент горных пород и теплообмен “теплоноситель - порода" меняется в зависимости от режима работы залежи и скважины. Это объясняется влиянием температуры, перепада температуры на влажность, вязкость, сжимаемость, другие свойства пород, определяющие эффективность тепловой диффузии и коэффициент теплообмена между флюидом и горными породами.

Научная новизна. Разработаны уточненные уравнения теплового баланса энергии при радиальной фильтрации и лифтинге продукции скважины, которые выгодно отличаются от применяемых в современных методах расчета введением коэффициента дросселирования флюида в пласте при неадиабатическом процессе, учетом влияния среднеинтегральной температуры среды на эффективность теплопередачи (известные методики учитывают среднегеометрическую температуру пласта). Учитывается фактическое изменение молярной массы добываемого геотермального флюида в течение срока эксплуатации скважины (до 50 лет). Термогазодинамическая модель “скважинный приток - лифтинг” усовершенствована учетом переходного процесса охлаждения продуктивного пласта на первоначальном этапе (месяцы - годы) добычи геотермального флюида.

Практическая значимость. Разработанная математическая модель позволяет уточнить расчет дебита скважины на $10-15 \%$. Разработанная модель относительно базовых методик позволяет в условиях термобарической интенсификации добычи флюида и бинарных технологий добычи “флюид - геотепло” уточнять на 20-30\% добычу тепла газоконденсатного скважиной. Математическая модель уточняет устьевые температуры природного газа.

Ключевые слова: дебит геотермального флюида, термический градиент, горная порода, параметрическое температурное поле, коэффициент теплообмена, эффект Джоуля-Томсона

\section{Article info}

Received: 11 December 2019

Accepted: 14 April 2020

Available online: 18 April 2020 